\title{
Kegiatan Public Relations Dalam Organisasi Kerukunan Keluarga Kawanua (KKK) untuk Melestarikan Budaya Minahasa
}

\author{
Chelsea Natalia, Suherman Kusniadji \\ Chelsnatalia97@gmail.com, Kusniadjiherman@gmail.com \\ Fakultas Ilmu Komunikasi Universitas Tarumanagara
}

\begin{abstract}
As an organization that stands with a cultural background, the activities within the Kawanua Family Harmony organization are inseparable from the Minahasa culture. This study discusses the activities of the Kawanua Family Harmony organization to preserve Minasaha's culture. This research uses several communication theories, among others, organizational communication theory, group communication, events and also Public Relations. In this study the authors used qualitative research methods with a case study approach. The author conducts structured interviews and observations in the Kawanua Family Harmony activities. Through the results of the observations that the author made, the author found that there was a form of preservation of Minahasa culture that occurred in the organizational communication and communication of the Kawanua group through Organizational Communication, Group Communication, Events and Public Relations. From this study the authors can conclude that through communication activities there can be a form of preservation of Minahasa culture.
\end{abstract}

Keywords: culture, public relations, organizational communication theory, events.

\begin{abstract}
Abstrak
Sebagai sebuah organisasi yang berdiri dengan latar belakang budaya, maka kegiatan di dalam organisasi Kerukunan Keluarga Kawanua ini tidak terlepas dengan budaya Minahasa. Penelitian ini membahas mengenai kegiatan organisasi Kerukunan Keluarga Kawanua untuk melestarikan budaya Minahasa. Penelitian ini menggunakan beberapa teori komunikasi antara lain, teori komunikasi organisasi, komunikasi kelompok, event dan juga Public Relations. Penulis menggunakan metode penelitian kualitatif dengan pendekatan studi kasus. Penulis melakukan wawacara terstruktur dan juga observasi di dalam kegiatan Kerukunan Keluarga Kawanua. Melalui hasil pengamatan, penulis menemukan ada bentuk pelestarian budaya Minahasa yang terjadi didalam komunikasi organisasi dan komunikasi kelompok Kawanua melalui komunikasi organisasi, komunikasi kelompok, event dan Public Relations. Dari penelitian ini, penulis dapat mengambil kesimpulan bahwa melalui kegiatan komunikasi dapat terjadi bentuk pelestarian budaya Minahasa.
\end{abstract}

Kata Kunci: Komunikasi Organisasi, Event, Public Relations, pelestarian budaya

\section{Pendahuluan}

Masing-masing budaya mempunyai keunikan dan perbedaannya masingmasing, baik dari sejarah, perayaan, adat istiadat, nilai-nilai, dan bahasanya hal ini menjadikan Indonesia negara yang kaya akan kebudayaan. Kekayaan budaya ini menjadi salah satu identitas bangsa Indonesia yang harus dijaga dan dilestarikan. Daerah-daerah dan masyarakat tersebut yang bertanggung jawab untuk melestarikan 
budayanya baik dengan cara melindungi, menerapkan dan juga mengajarkan kepada generasi mudanya supaya budaya tersebut tidak punah.

Kekayaan budaya Indonesia pun diakui oleh negara lain sehingga pernah timbul konflik bahwa budaya Indonesia dicuri oleh negara lain. Permasalahan seperti ini akan timbul bila masyarakat Indonesia tidak menjaga dan melestarikan budayanya. Maka dari itu, melindungi dan melestarikan budaya Indonesia harus dimulai dari masyarakat itu sendiri. Namun seiring perkembangan jaman dan teknologi, perubahan demografi pun terjadi sehingga banyak masyarakat atau penduduk yang melakukan migrasi untuk menunjang kehidupannya atau dengan alasan dan keperluan pribadi yang membuat masyarakat tersebut pindah dari tempat asalnya. Meskipun terjadi migrasi yang dilakukan oleh penduduk asli suatu daerah, beberapa upaya pun tetap dilakukan untuk menjaga budaya asli daerahnya, seperti tetap menerapkan budaya tersebut dalam keluarganya, tetap menggunakan bahasa daerah, dan lain-lain upaya yang dapat dilakukan untuk menjaga suatu budaya.

Seringkali juga muncul ikatan atau komunitas yang bertujuan untuk merangkul para masyarakat daerah yang melakukan migrasi ke sebuah kota baru. Salah satunya adalah Kerukunan Keluarga KAWANUA. Organisasi ini didirikan dengan latar belakang budaya sehingga bisa merangkul keluarga suku Minahasa yang tinggal di luar Minahasa, sehingga dapat melakukan komunikasi budaya dan juga melestarikan budayanya meskipun berada di luar Minahasa. Dalam sebuah organisasi yang berlatar belakang budaya, membuat organisasi ini banyak diisi dengan konten-konten budaya. Sehingga tidak menutup kemungkinan juga ada bentuk kegiatan budaya yang bisa mendukung masyarakat Kawanua dalam melestarikan budaya Minahasa.

Dalam sebuah organisasi bisa terjadi beberapa bentuk kegiatan komunikasi dan bisa dilakukan dalam waktu yang bersamaan. Komunikasi yang efektif akan membuat pesan tersebut lebih mudah diterima dan dipahami oleh penerima pesan. Penulis melihat bahwa sangat besar peran komunikasi untuk melestarikan budaya. Beragam bentuk komunikasi yang dapat dilakukan untuk melestarikan budaya. Dengan beragamanya bentuk dan kegunaan dari kegiatan komunikasi dan juga melihat pentingnya masyarakat untuk menjaga kelestarian budaya daerahnya, maka penulis melalukan penelitian dengan judul "Analisis Kegiatan Komunikasi Masyarakat Kawanua dalam Melestarikan Budaya Minahasa."

Menurut Everett M. Rogers dan D. Lawrence Kincaid, komunikasi diartikan sebagai suatu proses antara dua orang atau lebih membentuk atau melakukan pertukaran informasi dengan satu sama lainnya yang pada gilirannya akan tiba pada saling pengertian yang mendalam (Canagara, 2011).

Komunikasi organisasi adalah pengiriman dan penerimaan berbagai pesan organisasi di dalam kelompok formal maupun informal dari suatu organisasi. Terdiri lebih dari satu individu membuat komunikasi organisasi menjadi salah satu bentuk komunikasi yang dilakukan selain komunikasi antarpribadi (Wiryanto, 2005). Ada juga fungsi-fungsi dari komunikasi organisasi menurut Liliweri (dalam Ruliana, 2014), ada dua fungsi komunikasi organisasi yaitu fungsi umum dan fungsi khusus.

Fungsi umum yaitu untuk menyampaikan atau memberikan informasi kepada individu atau kelompok, untuk mendapatkan gagasan dan ide, pendapat, dan fakta, untuk meningkatkan kemampuan para karyawan, untuk menentukan bagian-bagian dan struktur didalam sebuah organisasi baik pemimpinin dan anggota, dan besaran kekuasaan dan kewenangan, serta menentukan bagaimana menangani sejumlah orang, bagaimana memanfaatkan sumber daya manusia, dan mengalokasikan manusia, mesin, metode, dan teknik dalam organisasi dan yang kedua yaitu fungsi 
khusus untuk membuat para karyawan melibatkan diri ke dalam isu-isu organisasi, untuk membuat para karyawan menciptakan dan menangani relasi antar sesama bagi peningkatan produk organisasi, untuk membuat para karyawan memiliki kemampuan untuk menangani dan mengambil keputusan-keputusan dalam suasana yang ambigu dan tidak pasti.

Arah aliran informasi dalam organisasi sebagaimana dikemukakan oleh Pace dan Faules (2010) sebagai berikut: komunikasi ke bawah, dalam sebuah organisasi berarti bahwa informasi mengalir dari jabatan berotoritas lebih tinggi (pemimpin) kepada anggota yang berotoritas lebih rendah; komunikasi ke atas, dalam sebuah organisasi berarti bahwa informasi mengalir dari tingkat yang lebih rendah (bawahan) ke tingkat yang lebih tinggi; komunikasi horizontal, terdiri dari penyampaian informasi di antara rekan-rekan sejajaran dalam unit kerja yang sama.

Ronald B. Adler dan George Rodman membagi tipe kelompok menjadi empat yaitu: Kelompok Belajar (Learning Group) tidak hanya ada pada lingkungan pendidikan akademik, tetapi ada pada setiap kelompok yang memiliki tujuan untuk menambah pengetahuan atau kemampuan tentang suatu subjek; Kelompok Pemecah Masalah (Problem Solving Group) bertujuan untuk menyelesaikan masalah yang terjadi pada anggota dalam kelompok; Kelompok Pertumbuhan (Growth Group) berfokus pada pengajaran kepada anggota kelompok untuk menjadi pribadi yang lebih baik; Kelompok Sosial (Social Group) bertujuan untuk memenuhi kebutuhan bersosialisasi anggota kelompok.

Pengertian Interaksi Sosial menurut Walgito (2007) adalah hubungan antara individu dengan individu lain. salah satu individu ini dapat mempengaruhi individu yang lain, sehingga terdapat hubungan yang saling timbal balik. Hubungan ini dapat terjadi antara individu, individu dengan kelompok atau antar kelompok. Adapun Basrowi (2014) mengemukakan interaksi sosial adalah hubungan dinamis yang mempertemukan orang dengan orang, kelompok dengan kelompok, maupun orang dengan kelompok manusia. Bentuknya tidak hanya bersifat kerjasama, tetapi juga berbentuk tindakan, persaingan, pertikaian dan sejenisnya.

Menurut Sarwono dan Meinarno (2009), interaksi sosial adalah hubungan timbal balik yang saling mempengaruhi antara individu dengan individu lain, individu dengan kelompok, dan kelompok dengan kelompok lain.

Setiap event selalu mempunyai tujuan utama untuk apa diselenggarakan. Salah satu tujuan utama dari event ada pada target sasarannya atau target pengunjung yang diharapkan akan hadir dalam event yang diadakan. Menurut Any Noor (2009) kunci utamanya adalah pengunjung mengetahui manfaat apa yang akan didapat melalui sebuah event (2009).

Menurut J.H. Wright, Public Relations yang modern adalah suatu rencana tentang kebijaksanaan dan kepemimpinan yang akan menanamkan kepercayaan kepada publik dan menambah pengertian mereka (Saputra, 2011). Menurut Edward L. Berneys (dalam Mukarom dan Wijaya, 2015), public relations memiliki tiga macam arti yaitu memberikan informasi kepada masyarakat, persuasi ini dimaksudkan untuk mengubah sikap dan tingkah laku masyarakat terhadap lembaga untuk kepentingan kedua belah pihak, usaha untuk mengintegrasikan sikap dan perbuatan antar lembaga dengan sikap perbuatan masyarakat dan sebaliknya.

Menurut Lee (2000), budaya adalah keseluruhan nilai, norma kepercayaan, dan pemahaman dari interpretasi pengalaman yang melingkupi sekelompok manusia. Budaya membentuk pola kehidupan dan memandu bagaimana cara manusia berpikir, merasakan, dan berkomunikasi (Julia, 2013). 


\section{Metode Penelitian}

Peneliti menggunakan metode penelitian kualitatif. Menurut Moleong (2008) penelitian kualitatif adalah penelitian yang menghasilkan prosedur analisis yang tidak menggunakan prosedur analisis statistik atau cara kuantifikasi lainnya. Strategi analisis kualitatif, biasanya tidak digunakan sebagai alat mencari data dalam arti frekuensi akan tetapi digunakan untuk menganalisis proses sosial yang berlangsung dan makna dari fakta-fakta yang tampak dipermukaan itu. Dengan demikian, analisis kualitatif digunakan untuk memahami sebuah proses dan fakta dan bukan sekedar untuk menjelaskan fakta tersebut (Bungin 2007).

Peneliti menggunakan metode penelitian deskriptif kualitatif karena peneliti ingin membuat deskripsi dan gambaran secara faktual, akurat dan sistematis mengenai bentuk kegiatan komunikasi Masyarakat Kawanua untuk melestarikan budaya Minahasa dengan data yang terkumpul baik berupa foto, cacatan lapangan, transkrip wawancara, tape recorder, catatan atau bentukan memo lain yang penulis dapatkan untuk mendukung proses analisis dalam pembahasan.

Penulis melakukan penelitian kualitatif dengan metode studi kasus yang dilakukan pada sebuah organisasi kebudayaan yaitu Kerukunan Keluarga Kawanua. Menurut Sugiyono (2011) mengatakan bahwa objek penelitian adalah sasaran untuk mendapatkan data dengan tujuan dan kegunaan tertentu tentang sesuatu hal yang objektif, valid, dan reliabel tentang suatu hal. Peneliti menyimpulkan bahwa objek penelitian adalah masalah utama yang menjadi sasaran untuk diungkapkan, dibahas dan diuraikan secara objektif, valid dan reliable melalui penelitian. Objek penelitian dalam penelitian ini adalah kegiatan komunikasi masyarakat Kawanua dalam melestarikan kebudayaan Minahasa.

Teknik pengumpulan data yang digunakan dalam penelitian ini adalah teknik wawancara terstruktur, teknik observasi, dan dokumentasi. Teknik wawancara yang digunakan yaitu wawancara terstruktur karena pertanyaan pertanyaan sudah disiapkan secara terstruktur dan mengikuti pedoman pedoman wawancara yang sistematis dan lengkap untuk mengumpulkan data yang dicari.

Observasi merupakan teknik pengumpulan data dengan melakukan pengamatan terhadap objek secara langsung yang bertujuan untuk melihat kegiatan objek dengan dekat. Adanya observasi yang penulis lakukan untuk mengetahui bentuk Komunikasi Kelompok yang terjadi didalam Kerukunan Keluarga Kawanua pada saat ada kegiatan latihan menari. Penulis mengikuti beberapa kegiatan yang dilalukan sebagai bentuk observasi untuk mendukung pengumpulan data. Terakhir adalah dokumentasi.

Sumber data pada penelitian ini dikelompokan menjadi dua golongan, yaitu: Data primer merupakan data yang diperoleh secara langsung dari objek penelitian perorangan, kelompok, dan organisasi (Ruslan, 2013: 29). Dengan demikian, data primer diperoleh dari sumber data primer. Data primer diperoleh peneliti melalui dua orang Informan yang aktif sebagai Public Relation Nyong Noni Kawanua dan juga salah satu anggota muda Kerukunan Keluarga Kawanua yang bernama Stevan Rinno Ticoalu dan Sesca Maria. Penulis juga mendapatkan informasi dari key informant yang mengetahui, memahami, dan menguasi tiap tahapan organisasi tersebut. Oleh karena itu, peneliti memilih seorang key informant yaitu Franky Boseke. Franky adalah salah satu pengurus di departemen kebudayaan dan juga menjabat sebagai salah satu presidium di Organisasi Muda Katolik Kawanua. 
Teknik analisis data yang penulis gunakan dalam penelitian ini melalui lima tahapan yaitu reduksi data. Mereduksi data yang penulis lakukan adalah mengumpulkan informasi yang terkait dengan topik penelitian dan mengelompokkan dengan topik topik yang lebih kecil. Lalu masuk kepada pengumpulan data, data yang dikelompokan disusun sehingga berbentuk rangkaian informasi yang berhubungan dengan masalah penelitian. Penyajian data melakukan interpretasi data yaitu menginterpretasikan apa yang telah diinterpretasikan oleh informan terhadap masalah yang diteliti. Lalu penarikan kesimpulan berdasarkan hasil pengumpulan data yang telah disusun sehingga dapat memberi jawaban atas penelitian. Dan yang terakhir adalah evaluasi, tahap ini dimaksud untuk menghindari kesalahan interpretasi penulis dari hasil wawancara sejumlah informan.

\section{Hasil Temuan dan Diskusi}

Kerukunan Keluarga Kawanua berdiri dari latar belakang budaya, sehingga komunikasi dan kegiatan-kegiatan yang diadakan di dalam organisasi ini juga berhubungan dengan budaya. Komunikasi yang terjadi di dalamnya juga masih terdapat bentuk organisasi sehingga masih terdapat bahasan lain selain kebudayaan. Menurut Everett M. Rogers dan D. Lawrence Kincaid, komunikasi diartikan sebagai suatu proses antara dua orang atau lebih membentuk atau melakukan pertukaran informasi dengan satu sama lainnya yang pada gilirannya akan tiba pada saling pengertian yang mendalam (Canagara, 2011).

Franky selaku key informant juga mengakui bahwa di dalam organisasi Kerukunan Keluarga Kawanua terjadi komunikasi untuk berhubungan sesama individu karena sebagai makhluk sosial tidak bisa hidup secara individu tanpa orang lain, dan salah satu tujuan didirikannya organisasi ini adalah untuk berkomunikasi dengan sesama yang satu tanah daerah. Dalam bentuk komunikasi yang dilakukan ada pesan atau informasi yang tersampaikan baik disengaja ataupun tidak disengaja

Kerukunan Keluarga Kawanua juga tidak terlepas dari bentuk komunikasi organisasi. Menurut Wiryanto (2005) komunikasi organisasi adalah pengiriman dan penerimaan berbagai pesan organisasi di dalam kelompok formal maupun informal dari suatu organisasi. Terdiri lebih dari satu individu membuat komunikasi organisasi menjadi salah satu bentuk kegiatan komunikasi yang dilakukan didalam Kerukunan Keluarga Kawanua. Dengan terjadinya komunikasi yang membahas tentang budaya dan kepentingan organisasi didalamnya, komunikasi organisasi ini termasuk dalam fungsi informatif. Karena adanya penerimaan informasi baru, baik untuk anggota dan juga bagi tatanan manajemen.

Bentuk informasi yang terjadi kepada anggota di Kerukunan Keluarga Kawanua adalah tugas-tugas atau hasil keputusan-keputusan yang disampaikan dari ketua ketua divisi masing-masing ataupun dari ketua umum. Sedangkan bentuk informasi yang diterima oleh tatanan manajemen atau Ketua Divisi KKK adalah pengajuan mengenai kegiatan yang akan dilaksanakan dan juga bisa dalam bentuk laporan kegiatan ataupun saran serta hasil pemecahan masalah bersama-sama. Hal ini dijelaskan Franky saat penulis sedang menanyakan bentuk aliran informasi yang terjadi di dalam organisasi dan kelompok Kerukunan keluarga Kawanua.

Bentuk komunikasi yang dijalankan secara baik dikarenakan orang Minahasa yang setanah air mempunyai nilai kekeluargaan sehingga bentuk komunikasi yang dilakukan untuk memberikn tugas atau perintah pun tidak menggunakan wewenang atau kekuasaan. Bentuk komunikasi yang dilakukan ini termasuk juga dalam fungsi 
persuasi. Pemimpin di organisasi Kerukunan Keluarga Kawanua memilih untuk menjalankan fungsi persuasif untuk menyampaikan tugas atau perintah supaya, hasil yang dikerjakan lebih maksimal dan sesuai dengan yang diharapkan. Selain itu dengan bentuk persuasi, anggota pun akan merasa lebih dihargai sehingga terjalin bentuk hubungan dan bentuk komunikasi yang baik antara pemimpin dan juga anggotanya. Ada juga fungsi integratif secara informal yang dilakukan oleh Kerukunan Keluarga Kawanua berupa untuk melibatkan partisipasi anggota organisasi sehingga para anggota tidak jenuh dan aktif dalam kegiatan berorganisasi.

Dihubungkan dengan teori mengenai tipe tipe komunikasi kelompok menurut Ronald B. Adler dan George Rodman ada empat tipe-tipe kelompok yaitu kelompok belajar, kelompok pemecah masalah, kelompok sosial, dan kelompok pertumbuhan. Sehingga dapat disimpulkan KKK merupakan tipe Kelompok Belajar (Learning Group). Tidak hanya sebagai kelompok balajar, namun disisi lain anggota dari KKK juga melakukan komunikasi dengan sesamanya sebagai bentuk sosialisasi yang makhluk sosial mempunyai kebutuhan untuk berinteraksi dengan makhluk lain karena tidak dapat hidup sendiri. Sehingga, KKK juga termasuk kedalam tipe kelompok sosialisasi. Dalam Tipe kelompok pemecah masalah, dan tipe kelompok pertumbuhan, KKK hanya menganut sedikit model tipe kelompok tersebut dalam hal-hal pertemuan rapat untuk membahas teknis-teknis dan keperluan administratif organisasi.

Dalam kegiatan KKK sesekali juga diadakan Event yang berlatarkan belakangkan budaya. Event yang diadakan ini bertujuan untuk memperkenalkan budaya Minahasa supaya tetap dikenal sebagai budaya negara Indonesia dan tidak punah. Bentuk Event ini adalah salah satu upaya pelestarian budaya. Event yang dilaksanakan juga melibatkan banyak partisipan baik dari pihak Kerukunan Keluarga Kawanua dan juga hadirin dari acara tersebut. Dengan memperkenalkan budaya Minahasa melalui event, jangkauan yang terlibat akan lebih besar shingga efektif dalam melestarikan budaya Minahasa.

Selain melestarikan budaya melalui komunikasi kelompok dan event, KKK memahami bentuk komunikasi lain yang dapat dimaksimalkan dalam melestarikan budaya. Di dalam KKK terdapat juga bentuk Public Relation atau yang dikenal sebagai Nyong Noni Kawanua. Nyong Noni Kawanua selaku sebagai Public Relation dari KKK yang bertujuan untuk menjalin komunikasi antar Kawanua Muda dan juga sebagai wadah kreativitas untuk generasi muda Kawanua dan masyarakat luas supaya memahami budaya Minahasa. Sehingga bisa menjalin komunikasi dan juga menjaga kelestarian budaya.

Berdasarkan hasil wawancara dan observasi yang dilakukan penulis, ada beberapa bentuk kegiatan komunikasi yang dilakukan oleh organisasi Kerukunan Keluarga Kawanua yaitu komunikasi organisasi yang didalamnya juga terdapat komunikasi kelompok, event dan juga public relations untuk melestarikan budaya Minahasa. Berdasarkan ketiga bentuk kegiatan komunikasi yang dilakukan, penulis melihat bentuk kegiatan event paling dominan di dalam upaya untuk melestarikan budaya, karena sesuai dengan hasil wawancara yang penulis lakukan.

Dalam kegiatan event dibutuhkan persiapan untuk mencapai keberhasilan, dengan adanya persiapan event maka didalam Kerukunan Keluarga Kawanua terjadi bentuk pembelajaran dan bertambahnya pengetahuan mengenai budaya Minahasa dan juga saat event itu diadakan. Khalayak event bisa dari internal KKK dan juga masyarakat luar yang membuat pesan mengenai budaya Minahasa dapat meluas dan dapat diketahui oleh masyarakat luas. 


\section{Simpulan}

Berdasarkan hasil penelitian mengenai kegiatan komunikasi yang dilakukan oleh Masyarakat Kawanua untuk melestarikan budaya Minahasa, penulis dapat mengambil kesimpulan bahwa terjadi beberapa bentuk kegiatan komunikasi yang dilakukan di dalam Kerukunan Keluarga Kawanua.

Kerukunan Keluarga Kawanua melakukan beberapa kegiatan komunikasi yaitu komunikasi organisasi, komunikasi kelompok, event, dan juga menggunakan unsur Public Relation untuk melestarikan budaya Minahasa. Komunikasi organisasi dan komunikasi kelompok terjadi di dalam organisasi dan kegiatan-kegiatan KKK. Sedangkan bentuk kegiatan Public Relation terlihat dari didirikannya Nyong-Noni Kawanua dengan tujuan untuk memperkenalkan budaya Minahasa terhadap masyarakat supaya tidak punah. Hal ini ditujukan sebagai upaya melestarikan budaya Minahasa.

Dalam menjalankan sebuah organisasi tentu ada hambatan yang dialami yaitu banyak dari anggota KKK yang memiliki kesibukan masing-masing sehingga merasa tidak mempunyai waktu untuk ikut aktif dan juga merasa dan juga karena tujuan melestarikan budaya, terkadang dalam proses komunikasi terjadi sedikit kesulitan untuk berbicara menggunakan bahasa daerah. Banyak Kawanua muda lahir di Jakarta sehingga sudah jarang sekali menggunakan bahasa daerah.

\section{Ucapan Terima Kasih}

Penulis mengucapkan terima kasih kepada Tuhan YME, dosen pembimbing, orang tua, teman-teman serta kepada narasumber yang menjadi subjek dan objek penelitian serta seluruh pihak yang telah membantu penulis menyelesaikan penulisan skripsi ini baik secara langsung maupun tidak langsung.

\section{Daftar Pustaka}

Any, Noor. (2009). Management Event. Bandung: Alfabeta

Basrowi. (2014). Pengantar Sosiologi. Bogor: Ghalia Indonesia.

Bungin, Burhan. (2007). Metodologi Penelitian Kualitatif. Jakarta: PT Raja Grafindo Persada

Cangara, Hafied. (2011). Pengantar Ilmu Komunikasi. Jakarta: PT Raja Grafindo Persada.

Lexy, J Moleong. (2008) Metodologi Penelitian Kualitatif. Bandung: PT Remaja Rosdakarya

Mukarom, Zainal dan Mahibudin Wijaya Laksana. (2015). Manajemen Public Relations: Panduan Efektif Pengelolaan Hubungan Masyarakat. Bandung: CV Pustaka Setia

Ruslan, Rosady. (2006). Penelitian Public Relations dan Komunikasi. Jakarta: Raja Gravindo.

Sarwono, Sarlito W. \& Eko A. Meinarno. (2009). Psikologi Sosial. Jakarta: Penerbit Salemba Humanika 
Vol. 2, No. 2, Desember 2018, Hal 253-260

Sugiyono. (2011). Metode penelitian Kualitatif. Bandung: Alfabeta.

Wiryanto (2005). Pengantar Ilmu Komunikasi. Jakarta. PT. Grasindo.

Wood, Julia T. (2013). Komunikasi Interpersonal Interaksi Keseharian, Edisi 6. Jakarta: Salemba Humanika. 